ROBERT KOWALIK

JAROSŁAW GAWDZIK

Kielce University of Technology

BARBARA GAWDZIK

Jan Kochanowski University in Kielce

e-mail: rkowalik@tu.kielce.pl
Manuscript submitted 2019.11.04 - revised 2019.11.15, initially accepted for publication 2019.11.18, published in December 2019

\title{
RISK ANALYSIS OF ACCUMULATION OF HEAVY METALS FROM SEWAGE SLUDGE IN SOIL FROM THE SEWAGE TREATMENT PLANT IN STARACHOWICE
}

\author{
ANALIZA RYZYKA KUMULACJI METALI CIĘŻKICH \\ Z OSADÓW ŚCIEKOWYCH W GLEBIE POCHODZACYCH \\ Z OCZYSZCZALNI ŚCIEKÓW W STARACHOWICACH
}

DOI: 10.30540/sae-2019-022

\begin{abstract}
Sewage sludge from sewage treatment plants has important soil-forming and fertilizing properties. However, they cannot always be used for this purpose. One of the main reasons why sludge cannot be used for natural purposes is its heavy metal content. Sewage sludge from the treatment plant in Starachowice has been subjected to an analysis of the potential risk of heavy metals, especially in terms of their mobility and geoaccumulation. The calculations were made for the concentrations of heavy metals in sewage sludge taken from the treatment plant in Starachowice and in arable soil from the measurement point at the place of its potential use. Geoaccumulation index (Igeo) and potential ecological risk index (PERI) were calculated. The analysis of the results shows that although the geo-accumulation index and the level of potential ecological risk are high and dangerous in terms of agricultural or natural use of sediments, the percentage of metals has been recorded mainly in the immobile fraction from which they will not get into the soil.
\end{abstract}

Keywords: sewage sludge, geoaccumulation index (Igeo), potential ecological risk index (PERI), mobility of heavy metals

\section{Streszczenie}

Osady ściekowe z oczyszczalni ścieków mają istotne właściwości glebotwórcze i nawozowe. Nie zawsze jednak moga być one wykorzystywane do tego celu. Jedna z glównych przyczyn, dla których nie można wykorzystać osadów na cele przyrodnicze, jest zawartość w nich metali ciężkich. Osady ściekowe z oczyszczalni w Starachowicach zostały poddane analizie potencjalnego zagrożenia metalami ciężkimi, zwłaszcza pod względem ich mobilności i geoakumulacji. Obliczenia wykonano dla stężeń metali ciężkich w osadach ściekowych pobranych z oczyszczalni w Starachowicach oraz w glebie ornej z punktu pomiarowego w miejscu ich potencjalnego wykorzystania. Obliczono wskaźnik geoakumulacji (Igeo) oraz potencjalny wskaźnik ryzyka ekologicznego (PERI). Na podstawie analizy wyników można stwierdzi, iż pomimo że wskaźnik geokumulacji oraz poziom potencjalnego ryzyka ekologicznego sa wysokie i niebezpieczne pod katem rolniczego badź przyrodniczego wykorzystania osadów, to udziat procentowy metali odnotowano głównie we frakcji niemobilnej, z której nie będa one przedostawać się do gleby.

Slowa kluczowe: osady ściekowe, indeks geoakumulacji (Igeo), potencjalny indeks ryzyka ekologicznego (PERI), mobilność metali ciężkich

\section{INTRODUCTION}

Municipal sewage sludge is formed as a by-product of processes carried out at sewage treatment plants. At present, an increase in the amount of sewage sludge

\section{WPROWADZENIE}

Komunalne osady ściekowe powstają jako produkt uboczny procesów prowadzonych na oczyszczalni ścieków. Aktualnie można zaobserwować w Polsce, 
generated can be observed in Poland as well as in the world [1]. There are many possibilities of utilization of the sludge created in this way. The form of natural sludge utilization is particularly beneficial, mainly due to its high fertilizer and soil-forming properties. The choice of sewage sludge management method is dictated especially by the number and properties of sewage sludge [2]. Moreover, it is subject to legal regulations, among others: In addition, it is subject to legal regulations, among others: the Waste Act [3], the Regulation of the Minister of the Environment on municipal sewage sludge [4], the Regulation of the Minister of Economy on criteria and procedures for allowing waste to be deposited at a given type of landfill site [5]. Sewage sludge, showing high fertilizer values, may be used in agriculture as an organic fertilizer, provided that the content of micropollutants does not cause negative effects in the soil environment [6]. The aim of this study was to assess the contamination and potential ecological risk of six selected heavy metals. In the assessment of potential ecological risks, GAI and PERI indicators were used and the mobility of heavy metals was taken into account. All tested indicators and heavy metals limits set by the Regulation were compared and appropriate conclusions were reached.

\section{MOBILITY OF HEAVY METALS AND RISK INDICATORS FOR ACCUMULATION OF HEAVY METALS IN SOIL}

A two-kilogram sample of sewage sludge collected before the hygienization process from all the objects was used to investigate the mobility of metals. The determinations were performed with the Perkin-Elmer 3100 F-AAS atomic absorption spectrometer with a ball valve option. The investigations were carried out with the use of BCR sequential extraction method. Mineralisation of the residual fraction was carried out with the use of royal water. The collected sample was reduced to $8 \mathrm{~g}$ and dried (air-dry conditions) at $20^{\circ} \mathrm{C}$ for 48 hours. Then $0.5 \mathrm{~g}$ of sewage sludge with $80 \%$ hydration was weighed and transferred to a rotor tube per $100 \mathrm{~cm}^{3}$. After adding $40 \mathrm{~cm}^{3}$ of 0.11 molar acetic acid solution, the test was shaken for 16 hours at room temperature. The extract obtained was separated from the sediments by centrifugation (4000 rpm). The content of water-soluble metals in the obtained liquid was determined. The sewage sludge was washed with $20 \mathrm{~cm}^{3}$ of distilled water by shaking and centrifugation. Then $40 \mathrm{~cm}^{3}$ of $0.1 \mathrm{~mol}$ hydroxylamine hydrochloride solution with $\mathrm{pH}=2$ jak również na świecie wzrost ilości powstających osadów ściekowych [1]. Istnieje wiele możliwości zagospodarowania tak powstałych osadów. Szczególnie korzystna jest forma przyrodniczego wykorzystania osadów, głównie $\mathrm{z}$ uwagi na wysokie walory nawozowe, jak i glebotwórcze. Wybór metody zagospodarowania osadów ściekowych podyktowany jest szczególnie ilością i właściwościami osadów ściekowych [2]. Ponadto podlega regulacjom prawnym, między innymi: Ustawie o odpadach [3], Rozporządzeniu Ministra Środowiska w sprawie komunalnych osadów ściekowych [4], Rozporządzeniu Ministra Gospodarki w sprawie kryteriów oraz procedur dopuszczania odpadów do składowania na składowisku odpadów danego typu [5]. Osady ściekowe, wykazując wysokie wartości nawozowe, mogą być wykorzystane w rolnictwie jako nawóz organiczny, pod warunkiem że zawartość mikrozanieczyszczeń nie wywoła negatywnych skutków w środowisku glebowym [6]. Badanie to miało na celu ocenę zanieczyszczenia i potencjalnego ryzyka ekologicznego sześciu wybranych metali ciężkich. W ocenie potencjalnego ryzyka ekologicznego wykorzystano wskaźniki GAI, PERI, a także uwzględniono mobilność metali ciężkich. Porównano wszystkie badane wskaźniki oraz limity zawartości metali ciężkich wyznaczone przez rozporządzenie, a następnie wyciągnięto odpowiednie wnioski.

\section{MOBILNOŚĆ METALI CIĘ̇̇KICH I WSKAŹNIKI RYZYKA KUMULACJI METALI CIĘŻKICH W GLEBIE}

Do badań mobilności metali wykorzystano uprzednio pobraną dwukilogramową próbę osadów ściekowych przed procesem higienizacji ze wszystkich obiektów. Oznaczenia wykonano za pomocą spektrometru absorpcji atomowej firmy Perkin-Elmer 3100 F-AAS $\mathrm{w}$ opcji z zaworem kulkowym. Badania przeprowadzono metodą ekstrakcji sekwencyjnej BCR. Mineralizację frakcji rezydualnej przeprowadzono przy pomocy wody królewskiej. Pobraną próbę zredukowano do masy $8 \mathrm{~g}$ i suszono (warunki powietrzno-suche) w temperaturze $20^{\circ} \mathrm{C}$ w czasie 48 godzin. Następnie odważono 0,5 g osadów ściekowych o uwodnieniu $80 \%$ i przeniesiono do probówki wirnikowej na $100 \mathrm{~cm}^{3}$. Po dodaniu $40 \mathrm{~cm}^{3}$ 0,11-molowego roztworu kwasu octowego próbę wytrząsano 16 godzin w temperaturze pokojowej. Uzyskany ekstrakt oddzielono od osadów poprzez wirowanie (4000 obr./min). W otrzymanej cieczy oznaczono zawartość metali rozpuszczalnych w wodzie. Osady ściekowe przemyto $20 \mathrm{~cm}^{3}$ wody destylowanej poprzez wytrząsanie i wirowanie. Następnie do osadów ściekowych dodano $40 \mathrm{~cm}^{3}$ 0,1-mo- 
was added to the sewage sludge. Nitric acid was used to adjust $\mathrm{pH}$. The procedure was the same as in the previous stage (shaken and centrifuged) $[11,12]$. In the liquid the metals of fraction II were determined and sewage sludge was washed away. Sewage sludge was transferred quantitatively to quartz evaporation chambers and $10 \mathrm{~cm}^{3}$ of $30 \%$ hydrogen peroxide was added. The content of the evaporator was heated in a water bath at $85^{\circ} \mathrm{C}$ for one hour. The activity was repeated by adding 8.8 molar solution of hydrogen peroxide to the sewage sludge $\left(10 \mathrm{~cm}^{3}\right)$. After cooling down to room temperature, the sewage sludge was transferred to rotor tubes and $50 \mathrm{~cm}^{3}$ of ammonium acetate solution $\left(1 \mathrm{~mol} / \mathrm{dm}^{3}, \mathrm{pH}=2\right.$ after $\mathrm{HNO}_{3}$ correction) was added. The sample was shaken for 16 hours and then the sediment was separated from the extract. Metals of fraction III were determined in the solution. Sewage sludge was washed and dried to constant weight. Mineralisation of the residual fraction was carried out with the participation of royal water. A conical flask with a volume of $300 \mathrm{~cm}^{3}$ containing $0.5 \mathrm{~g}$ of sewage sludge was mixed with 30 $\mathrm{cm}^{3} \mathrm{HCl}$ and $10 \mathrm{~cm}^{3} \mathrm{HNO}_{3}$. The contents of the flask were heated for 30 minutes and then evaporated to dryness. After cooling, $25 \mathrm{~cm}^{3} \mathrm{HCl}(1+5)$ was added to dissolve the sewage sludge and transferred to a volumetric flask and topped up with distilled water to $50 \mathrm{~cm}^{3}$, then the contents of the flask were mixed and filtered into a dry vessel. The metals of fraction IV were determined in the filtrate. Heavy metal content in the extracts obtained was determined according to ISO 9001:2000 on the Perkin-Elmer 3100 F-AAS atomic absorption spectrophotometer in four independent samples of sewage sludge. The recovery control was performed on the basis of certified reference material BCR CRM 143R. The results were analyzed statistically to exclude thick errors. Dixon and Grubbs tests were used for this purpose [11, 13].

\subsection{Risk indicators for accumulation of heavy metals in soil}

\section{Geocumulation index of heavy metal in soil (GAI)}

In order to assess the degree of accumulation of heavy metals of anthropogenic origin in the soil, the Geocumulation Index (GAI) is used, which is described in equation $[14,15]$ :

$$
\mathrm{GAI}=\log _{2} \frac{C_{n}}{1.5 B_{n}}
$$

lowego roztworu chlorowodorku hydroksyloaminy $\mathrm{o} \mathrm{pH}=2$. Do korekty $\mathrm{pH}$ wykorzystano kwas azotowy. Postępowano jak w poprzednim etapie (wytrząsano i wirowano) [11, 12]. W cieczy oznaczono metale frakcji II, a osady ściekowe przepłukano. Osady ściekowe przeniesiono ilościowo do parownic kwarcowych i dodano $10 \mathrm{~cm}^{3} 30 \%$ nadtlenku wodoru. Zawartość parownicy ogrzewano w łaźni wodnej w temperaturze $85^{\circ} \mathrm{C}$ w ciągu jednej godziny. Czynność powtórzono dodając do osadów ściekowych $10 \mathrm{~cm}^{3}$ 8,8-molowego roztworu nadtlenku wodoru. Po ochłodzeniu do temperatury pokojowej próby osadów ściekowych przeniesiono do probówek wirnikowych, po czym dodano $50 \mathrm{~cm}^{3}$ roztworu octanu amonu $\left(1 \mathrm{~mol} / \mathrm{dm}^{3}, \mathrm{pH}=2\right.$ po korekcie $\mathrm{HNO}_{3}$ ). Wytrząsano próbę 16 godzin, a następnie oddzielono osady od ekstraktu. W roztworze oznaczono metale frakcji III. Osady ściekowe przemyto i wysuszono do stałej masy. Mineralizację frakcji rezydualnej przeprowadzono z udziałem wody królewskiej. Do kolby stożkowej o objętości $300 \mathrm{~cm}^{3}$ zawierającej 0,5 g osadów ściekowych, dodano $30 \mathrm{~cm}^{3}$ stęż. $\mathrm{HCl}$ i $10 \mathrm{~cm}^{3}$ stęż. $\mathrm{HNO}_{3}$. Zawartość kolby ogrzewano przez 30 minut, następnie odparowano do sucha. Po ochłodzeniu dodano $25 \mathrm{~cm}^{3}$ $\mathrm{HCl}(1+5) \mathrm{w}$ celu rozpuszczenia osadów ściekowych i przeniesiono do kolby miarowej i uzupełniono wodą destylowaną do $50 \mathrm{~cm}^{3}$, następnie wymieszano i przesączono zawartość kolby do suchego naczynia. W przesączu oznaczono metale frakcji IV. Zawartość metali ciężkich w uzyskanych ekstraktach oznaczono zgodnie z ISO 9001:2000 na spektrofotometrze absorpcji atomowej Perkin-Elmer 3100 F-AAS, w czterech niezależnych próbkach osadów ściekowych. Kontrolę odzysku przeprowadzono w oparciu o certyfikowany materiał odniesienia BCR CRM 143R. Wyniki badań poddano analizie statystycznej celem wykluczenia błędów grubych. Wykorzystano w tym celu testy Dixona oraz Grubbsa $[11,13]$.

\subsection{Wskaźniki ryzyka kumulacji metali ciężkich w glebie \\ Wskaźnik geokumulacji metalu ciężkiego w glebie (GAI)}

W celu oceny stopnia kumulowania się w glebie metali ciężki pochodzenia antropogenicznego, stosuje się wskaźnik geokumulacji (GAI), który opisany jest równaniem $[14,15]$ :

$$
\mathrm{GAI}=\log _{2} \frac{C_{n}}{1,5 B_{n}}
$$


where:

$C_{n}$ - content of a given element from the group of heavy metals contained in sewage sludge, $\mathrm{mg} / \mathrm{kg}$ d.m. $B_{n}$ - content of a given element from the group of heavy metals present in the soil, $\mathrm{mg} / \mathrm{kg}$ d.m.

Table 1 presents the classification of the heavy metals geocumulation index.

\begin{tabular}{|c|l|}
\hline GAI index & \multicolumn{1}{|c|}{ Level of geocumulation of heavy metals } \\
\hline$<0$ & No pollution \\
\hline $0-1$ & No pollution, moderate pollution \\
\hline $1-2$ & Moderate pollution \\
\hline $2-3$ & Moderate pollution or high \\
\hline $3-4$ & High pollution \\
\hline $4-5$ & High or very high pollution \\
\hline$>5$ & Very high pollution \\
\hline
\end{tabular}

\section{Potential Environmental Risk Indicator (PERI)}

The Potential Environmental Risk Index (PERI) is a measure of the environmental risk of soil with heavy metals and is described in the following formulas $[14,16]$ :

$$
C_{f}^{i}=\frac{C_{D}^{i}}{C_{R}^{i}}
$$

where:

$C_{f}^{i}$ - pollution factor,

$C_{D}^{i}$ - concentration of the $i$-th element from the group of heavy metals present in sewage sludge, $\mathrm{mg} / \mathrm{kg}$ d.m.

$C_{R}^{i}$ - concentration of the $i$-th element from the group of heavy metals in the soil, $\mathrm{mg} / \mathrm{kg}$.

$$
E_{r}^{i}=T_{r}^{i} \cdot C_{f}^{i}
$$

where:

$E_{r}^{i}$ - indicator of the potential ecological risk of the $i$-th element from the group of heavy metals,

$T_{r}^{i}$ - toxicity factor of the $i$-th element from the group of heavy metals.

Heavy metals differ in the degree of toxicity, which takes into account the toxicity factor $\left(T_{r}^{i}\right)$ : lead -5 , cadmium -30 , chromium -2 , copper -5 , nickel -5 , zinc $-1[15]$.

The sum of indicators of potential ecological risk of heavy metals from sewage sludge in the ground is defined by the equation [15]: gdzie:

$C_{n}$ - zawartość danego pierwiastka z grupy metali ciężkich znajdującego się w osadach ściekowych, $\mathrm{mg} / \mathrm{kg} \mathrm{s.m}$.

$B_{n}$ - zawartość danego pierwiastka z grupy metali ciężkich znajdującego się w glebie, mg/kg s.m.

W tabeli 1 przedstawiono klasyfikację wskaźnika geokumulacji metali ciężkich.

Table 1. Classification of geocumulation index of heavy metals in soil [15]

Tabela 1. Klasyfikacja wskaźnika geokumulacji metali ciężkich w glebie [15]

\section{Wskaźnik potencjalnego ryzyka ekologicznego (PERI)}

Wskaźnik potencjalnego ryzyka ekologicznego (PERI) jest miarą zagrożenia ekologicznego gruntu metalami ciężkimi i opisany jest następującymi formułami $[14,16]$ :

$$
C_{f}^{i}=\frac{C_{D}^{i}}{C_{R}^{i}}
$$

gdzie:

$C_{f}^{i}$ - współczynnik zanieczyszczenia,

$C_{D}^{i}$ - stężenie $i$-tego pierwiastka z grupy metali ciężkich znajdującego się w osadach ściekowych, mg/ kg s.m.,

$C_{R}^{i}$ - stężenie $i$-tego pierwiastka z grupy metali ciężkich znajdującego w glebie, $\mathrm{mg} / \mathrm{kg}$

$$
E_{r}^{i}=T_{r}^{i} \cdot C_{f}^{i}
$$

gdzie:

$E_{r}^{i}$ - wskaźnik potencjalnego ryzyka ekologicznego i-tego pierwiastka z grupy metali ciężkich,

$T_{r}^{i} \quad$ - współczynnik toksyczności $i$-tego pierwiastka z grupy metali ciężkich.

Metale ciężkie różnią się stopniem toksyczności, co uwzględnia współczynnik toksyczności $\left(T_{r}^{i}\right)$ : ołów -5 , kadm -30 , chrom -2 , miedź -5 , nikiel -5 , cynk -1 [15].

Suma wskaźników potencjalnego ryzyka ekologicznego metali ciężkich $\mathrm{z}$ osadów ściekowych w gruncie jest definiowana równaniem [15]: 


$$
P E R I=\sum_{i=1}^{n} E_{r}^{i}
$$

Table 2 shows the degree of potential environmental risk in relation to the PERI value.

\begin{tabular}{|c|c|c|}
\hline$E_{r}^{i}$ & PERI & Potential environmental risk \\
\hline$<40$ & $<150$ & Low \\
\hline $40-80$ & $150-300$ & Medium \\
\hline $80-320$ & $300-600$ & High \\
\hline$>320$ & $>600$ & Very high \\
\hline
\end{tabular}

\section{MATERIALS AND METHODS}

Samples of sewage sludge taken from the sewage treatment plant in Starachowice in the Świętokrzyskie Voivodeship were used for the studies. The characteristics of the sewage treatment plant are presented in Table 4. A measurement point prepared by the Monitoring of Orne Soil Chemistry in Poland [8] was used as a comparison point of heavy metals content in soil, and a measurement point in Wąchock, the closest to the OŚ in Starachowice, was selected. The results of soil measurement tests are presented in Tables 5 and 6 . The sewage sludge collected from the sewage treatment plants under study mostly met the requirements of heavy metals content included in the regulation. Only the level of zinc was slightly higher than provided for in the regulation. The limits of heavy metals in terms of the use of sewage sludge in Poland and worldwide are presented in Table 3.

$$
\text { PERI }=\sum_{i=1}^{n} E_{r}^{i}
$$

W tabeli 2 przedstawiono stopień potencjalnego ryzyka zagrożenia ekologicznego w stosunku do wartości wskaźnika PERI.

Table 2. Interpretation of the potential environmental risk indicator value

Tabela 2. Interpretacja wartości wskaźnika potencjalnego ryzyka ekologicznego

\section{MATERIAŁY I METODY}

Do badań wykorzystano próbki osadów ściekowych pobranych z oczyszczalni ścieków w Starachowicach na terenie województwa świętokrzyskiego. Charakterystykę oczyszczalni przedstawiono $\mathrm{w}$ tabeli 4 . Jako punkt porównawczy zawartości metali ciężkich w glebie wykorzystano punkt pomiarowy sporządzony przez Monitoring Chemizmu Gleb Ornych w Polsce [8], wybrano punkt pomiarowy w Wąchocku, znajdujący się najbliżej OŚ w Starachowicach. Wyniki prób pomiarowych gleb przedstawiono w tabelach 5 i 6 . Osady ściekowe pobrane z badanych oczyszczalni w większości spełniały wymogi zawartości metali ciężkich zawarte w rozporządzeniu. Jedynie poziom cynku był nieznacznie wyższy, niż przewiduje to rozporządzenie. Limity metali ciężkich w aspekcie wykorzystania osadów ściekowych w Polsce oraz na świecie przedstawiono w tabeli 3.

Table 3. Normative limit values for heavy metals in sewage sludge for agricultural use [7]

\begin{tabular}{|c|c|c|c|c|c|c|}
\hline Metal & \multicolumn{6}{|c|}{ Permissible values for heavy metals intended for natural use } \\
\hline \multirow{2}{*}{ Region } & \multirow{2}{*}{$\begin{array}{c}\text { Poland } \\
\text { Regulation }\end{array}$} & \multirow{2}{*}{$\begin{array}{l}\text { EU Directive } \\
86 / 278 / \text { EEC }\end{array}$} & \multicolumn{2}{|c|}{ Chinese Regulation GB 18918-2002 } & \multirow{2}{*}{$\begin{array}{l}\text { USA Regulation } 40 \text { CFR } \\
\text { Part } 503,503.13\end{array}$} & \multirow{2}{*}{$\begin{array}{l}\text { South African Guideline } \\
\text { (Pollutant Class a) }\end{array}$} \\
\hline & & & $\mathrm{pH}<6.5$ & $\mathrm{pH}>6.5$ & & \\
\hline$C d$ & 20 & $20-40$ & 5 & 20 & 39 & 40 \\
\hline $\mathrm{Ni}$ & 300 & $300-400$ & 100 & 200 & 420 & 420 \\
\hline $\mathrm{Zn}$ & 2500 & $2500-4000$ & 500 & 1000 & 2800 & 2800 \\
\hline $\mathrm{Cu}$ & 1000 & $1000-1750$ & 250 & 500 & 1500 & 1500 \\
\hline $\mathrm{Cr}$ & 500 & - & 600 & 1000 & - & 1200 \\
\hline $\mathrm{Pb}$ & 750 & $750-1200$ & 300 & 1000 & 300 & 300 \\
\hline
\end{tabular}

Tabela 3. Normatywne wartości graniczne metali ciężkich w osadach ściekowych przeznaczonych do użytku w rolnictwie [7] 
Table 4. Characteristics of analysed sewage treatment plants [9]

Tabela 4. Charakterystyka analizowanych oczyszczalni ścieków [9]

\begin{tabular}{|c|c|c|c|c|c|}
\hline Location & Treatment plant type & RLM & $\begin{array}{c}\text { Sludge treatment } \\
\text { form }\end{array}$ & $\begin{array}{c}\text { Location of potential } \\
\text { use of sewage sludge }\end{array}$ & $\begin{array}{c}\text { Distance of the WWTP from the point of } \\
\text { potential use (km) }\end{array}$ \\
\hline Starachowice & Mechanical-biological & 95000 & Fermentation in WKF & Wąchock & 7.6 \\
\hline
\end{tabular}

\begin{tabular}{|c|c|}
\hline Heavy metal & Value at the measuring point \\
\hline $\mathrm{Cu}$ & 3.0 \\
\hline $\mathrm{Cr}$ & 3.3 \\
\hline $\mathrm{Cd}$ & 0.09 \\
\hline $\mathrm{Ni}$ & 2.4 \\
\hline $\mathrm{Pb}$ & 10.8 \\
\hline $\mathrm{Zn}$ & 19.3 \\
\hline
\end{tabular}

Table 5. Characteristics of analysed points of potential sewage sludge utilisation [10]

Tabela 5. Charakterystyka analizowanych punktów potencjalnego wykorzystania osadów ściekowych [10]

Table 6. Contents of a given element from the group of heavy metals in soils of agricultural land in Świętokrzyskie voivodship, $\mathrm{mg} / \mathrm{kg}$ d.m.[10].

Tabela 6. Zawartość danego pierwiastka z grupy metali ciężkich w glebach użytków rolnych województwa świętokrzyskiego, $m g / k g$ s.m.[10]

\begin{tabular}{|c|c|c|c|c|c|c|c|c|c|}
\hline Location & Soil type & $\begin{array}{l}\text { Bonitation } \\
\text { class }\end{array}$ & Complex & Soil species & $\mathrm{pH}\left(\mathrm{H}_{2} \mathrm{O}\right)$ & Caries [\%] & $\begin{array}{c}\text { Organic } \\
\text { carbon [\%] }\end{array}$ & $\begin{array}{c}\text { Total } \\
\text { nitrogen }\end{array}$ & C/N ratio \\
\hline $\begin{array}{l}\text { Wąchock/Wąchock/ } \\
\text { Świętokrzyskie }\end{array}$ & Deer soils & IVa & 5 (rye good) & Clay sand & 4.1 & 0.99 & 0.57 & 0.08 & 7.2 \\
\hline
\end{tabular}

The content of heavy metals from the analysed wastewater treatment plant is presented in Table 7.
Zawartość metali ciężkich pochodzących z analizowanej oczyszczalni ścieków przedstawiono w tabeli 7.

Table 7. Heavy metal content in sludge from the tested sewage treatment plant [8]

Tabela 7. Wyniki badań zawartości metali ciężki w osadach pochodzacych z badanej oczyszczalni ścieków [8]

\begin{tabular}{|c|c|c|c|c|c|c|}
\hline WWTP & Chromium, $\mathbf{m g} / \mathbf{k g}$ & Zinc, $\mathbf{~ m g} / \mathbf{k g}$ & Cadmium, $\mathbf{m g} / \mathbf{k g}$ & Copper, $\mathbf{~ m g} / \mathbf{k g}$ & Nickel, $\mathbf{~ m g} / \mathbf{k g}$ & Lead, $\mathbf{m g} / \mathbf{k g}$ \\
\hline Starachowice & 142.6 & 2777.0 & 2.4 & 196.0 & 43.9 & 56.8 \\
\hline
\end{tabular}

\section{RESEARCH RESULTS AND DISCUSSION}

Table 8 presents the level of heavy metals geocumulation in the agricultural soil of Świętokrzyskie Voivodeship from sewage sludge from the analysed sewage treatment plant.

\section{WYNIKI BADAŃ I DYSKUSJA}

W tabeli 8 przedstawiono poziom geokumulacji metali ciężkich w glebie rolnej województwa świętokrzyskiego z osadów ściekowych pochodzących z analizowanej oczyszczalni ścieków.

Table 8. Classification of the results of the heavy metals geocumulation index from sewage sludge in soil

Tabela 8. Klasyfikacja wyników wskaźnika geokumulacji metali ciężkich z osadów ściekowych w glebie

\begin{tabular}{|c|c|c|c|c|}
\hline \multirow{2}{*}{ Heavy Metal } & \multicolumn{4}{|c|}{ Wastewater treatment plant 01 } \\
\cline { 2 - 4 } & Cn, mg/kg s.m. & Bn, mg/kg s.m. & GAI & \multirow{2}{*}{ Level of geocumulation } \\
\hline $\mathrm{Pb}$ & 56.8 & 10.8 & 1.81 & Medium pollution \\
\hline $\mathrm{Cd}$ & 2.4 & 0.09 & 4.15 & High or very high pollution \\
\hline $\mathrm{Cr}$ & 142.6 & 3.3 & 4.85 & High or very high pollution \\
\hline $\mathrm{Cu}$ & 196.0 & 3.0 & 5.44 & Very high pollution \\
\hline $\mathrm{Ni}$ & 43.9 & 2.4 & 3.61 & High pollution \\
\hline $\mathrm{Zn}$ & 2777.0 & 19.3 & 6.58 & Very high pollution \\
\hline
\end{tabular}


Analysing the level of geocumulation of heavy metals in soil, it can be concluded that the dominant heavy metals causing high contamination are Copper, Cadmium, Chromium, and Zinc, while statistically the lowest risk of accumulation in soil is posed by Lead. However, in most cases the results are not satisfactory and a very high risk of heavy metals geocumulation dominates, despite the fact that sewage sludge from the examined plants meets the requirements of the permissible content of heavy metals for agricultural purposes according to the Regulation of the Minister of the Environment of 6 February 2015.

Table 9 presents the collective values of the potential environmental risk index for individual heavy metals from the sewage sludge.
Analizując poziom wskaźnika geokumlacji metali ciężkich w glebie, można stwierdzić, że dominującymi metalami ciężkimi powodującymi wysokie zanieczyszczenie są miedź, kadm, chrom, oraz cynk, natomiast statystycznie najmniejsze ryzyko akumulacji w glebie stwarza ołów. Jednakże w większości wyniki nie są zadowalające i dominuje bardzo wysokie zagrożenie geokumulacji metali ciężkich, pomimo, że osady ściekowe pochodzące z badanych oczyszczalni spełniają warunki dopuszczalnej zawartości metali ciężkich na cele rolnicze według rozporządzenia Ministra Środowiska z dnia 6 lutego $2015 \mathrm{r}$.

W tabeli 9 przedstawiono zbiorcza wartości wskaźnika potencjalnego ryzyka ekologicznego dla poszczególnych metali ciężkich pochodzących z badanych osadów ściekowych.

Table 9. Classification of the results of the potential environmental risk indicator

Tabela 9. Klasyfikacja wyników wskaźnika potencjalnego ryzyka ekologicznego

\begin{tabular}{|c|c|c|c|c|c|c|}
\hline \multicolumn{7}{|c|}{ WWTP Starachowice } \\
\hline \multirow{2}{*}{ Heavy Metal } & \multicolumn{5}{|c|}{ Sample } & \multirow{2}{*}{$\begin{array}{l}\text { Level of potential } \\
\text { environmental risks }\end{array}$} \\
\hline & $C_{D^{\prime}} \mathrm{mg} / \mathrm{kg} \mathrm{s.m.}$ & $C_{R^{\prime}} \mathrm{mg} / \mathrm{kg}$ & $C_{f}$ & $T_{r}$ & $E_{r}$ & \\
\hline $\mathrm{Pb}$ & 56.80 & 10.80 & 5.26 & 5.00 & 26.30 & Low \\
\hline $\mathrm{Cd}$ & 2.40 & 0.09 & 26.67 & 30.00 & 800.00 & Very high \\
\hline $\mathrm{Cr}$ & 142.60 & 3.30 & 43.21 & 2.00 & 86.42 & High \\
\hline $\mathrm{Cu}$ & 196.00 & 3.00 & 65.33 & 5.00 & 326.67 & Very high \\
\hline $\mathrm{Ni}$ & 43.90 & 2.40 & 18.29 & 5.00 & 91.46 & Medium \\
\hline $\mathrm{Zn}$ & 2777.00 & 19.30 & 143.89 & 1.00 & 143.89 & High \\
\hline
\end{tabular}

When analysing the results of the potential ecological risk indicator, it can be concluded that the only element of the heavy metal group which does not show any potential ecological risk is lead. The remaining elements pose a high risk of ecological pollution, the most toxic of which is cadmium.

\section{Heavy metal stability}

Table 10 presents the average heavy metals content in the dry matter of the sludge in four stability fractions obtained by sequential extraction of BCR. In most cases, the level of stability of the metals does not indicate a high environmental risk. This is due to the high content of heavy metals in stable fractions (F3 and F4).
Analizując wyniki wskaźnika potencjalnego ryzyka ekologicznego, można stwierdzić, że jedynym pierwiastkiem z grupy metali ciężkich, który nie wykazuje potencjalnego ryzyka zagrożenie ekologiczne jest ołów. Pozostałe pierwiastki stwarzają w większości wysokie ryzyko skażenia ekologicznego, wśród nich najbardziej toksyczny okazał się kadm.

\section{Stabilność metali ciężkich}

W tabeli 10 przedstawiono średnią zawartość metali ciężkich w suchej masie osadu w czterech frakcjach stabilności uzyskanych metodą ekstrakcji sekwencyjnej BCR.

W większości przypadków poziom stabilności metali nie wskazuje na wysokie zagrożenie ekologiczne. Spowodowane jest to wysokim udziałem zawartości metali ciężkich we frakcjach stablinych (F3 oraz F4). 
Table 10. Average content of heavy metals in dry mass of sludge from the sewage treatment plant in Starachowice in four stability fractions obtained by BCR sequential extraction method

Tabela 10. Średnią zawartość metali ciężkich w suchej masie osadu z oczyszczalni w Starachowicach w czterech frakcjach stabilności uzyskanych metodą ekstrakcji sekwencyjnej BCR

\begin{tabular}{|l|c|c|c|c|c|c|}
\hline \multicolumn{1}{|c|}{ Heavy Metal [mg/kg s.m.] } & $\mathbf{C u}$ & $\mathbf{C r}$ & $\mathbf{C d}$ & $\mathbf{N i}$ & $\mathbf{P b}$ & $\mathbf{Z n}$ \\
\hline Fraction I & 0.9 & 2.1 & 0.1 & 7.9 & 7.8 & 79.0 \\
\hline Fraction II & 1.2 & 0.9 & 0.3 & 3.2 & 1.0 & 275.0 \\
\hline Fraction III & 124 & 78.1 & 0.9 & 9.8 & 4.5 & 1491.0 \\
\hline Fraction IV & 69.9 & 61.5 & 1.1 & 23.0 & 43.5 & 932.0 \\
\hline
\end{tabular}

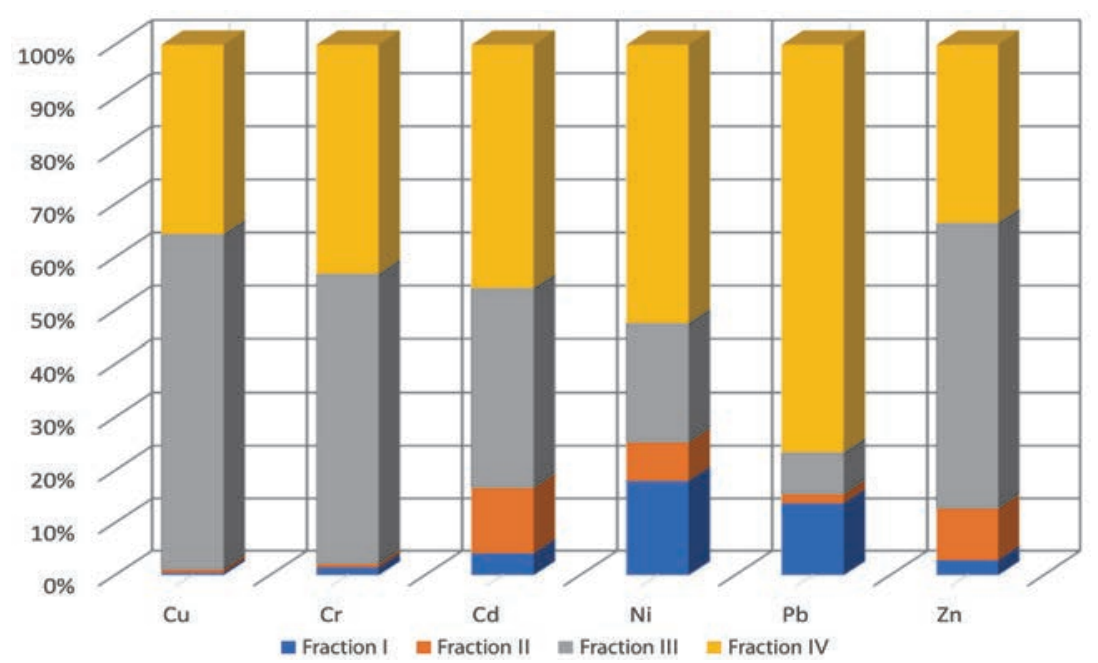

Fig. 1. Average percentage share of heavy metals in sewage sludge from the Starachowice treatment plant depending on the fraction

Rys. 1. Średni udział procentowy metali ciężkich w osadach ściekowych pochodzacych z oczyszczalni Starachowice w zależności od frakcji

\section{CONCLUSIONS}

The analysis of sewage sludge in terms of soil geocumulation index showed a very high risk of ecological contamination with heavy metals, mainly Copper, Cadmium, Chromium and Zinc. The calculated level of potential ecological risk also shows that for sewage sludge from the treatment plant in Starachowice and the soil sample used in the calculations, the risk of contamination with heavy metals is very high. This is due to the high values of the potential environmental risk index for Cadmium, Copper and Zinc. On the other hand, the sediment stability analysis showed a negligible share of cadmium, copper and zinc in the mobile fraction from which metals can migrate to the soil.

On the basis of the analysis of the results it can be concluded that although the geocumulation index and the level of potential ecological risk are high and dangerous for the agricultural or natural use of sediments, the percentage of metals was recorded mainly in the immobile fraction, from which they will not penetrate the soil.

\section{WNIOSKI}

Analiza osadów ściekowych pod kątem wskaźnika geokumulacji w glebie wykazała bardzo duże ryzyko skażenia ekologicznego metalami ciężkimi, głównie miedź, kadm, chrom oraz cynk. Również z obliczonego poziomu potencjalnego ryzyka ekologicznego wynika, że dla osadów ściekowych pochodzących z oczyszczalni w Starachowicach oraz przyjętej do obliczeń próbki gruntu ryzyko zanieczyszczenia metalami ciężkimi jest na bardzo wysokim poziomie. Wpływ na to mają wysokie wartości wskaźnika potencjalnego ryzyka ekologicznego dla kadmu, miedzi oraz cynku. Natomiast analiza osadu pod kątem stabilności wykazała znikomy udział kadmu, miedzi oraz cynku w frakcji mobilnej, z której metale mogą migrować do gleby.

Na podstawie analizy wyników można stwierdzi, iż pomimo że wskaźnik geokumulacji oraz poziom potencjalnego ryzyka ekologicznego są wysokie i niebezpieczne pod kątem rolniczego bądź przyrodniczego wykorzystania osadów, to udział procentowy 
Differences in the obtained results result from the fact that GAI and PERI indicators determine the sensitivity of the examined environment to heavy metals and show the risk resulting not only from concentrations of metals in sewage sludge, but also from their presence in the ground. Furthermore, PERI takes into account the toxicity of heavy metals. The BCR sequential extraction method, on the other hand, focuses on the assessment of heavy metal mobility. Despite the differences in results, the determination of these indicators should be integrated in order to comprehensively assess the quality of the environment and to analyse the risk of accumulation of heavy metals in soils. metali odnotowano głównie we frakcji niemobilnej, z której nie będą one przedostawać się do gleby.

Różnice w uzyskanych wynikach wynikają z faktu, że wskaźniki GAI i PERI określają wrażliwość badanego środowiska na metale ciężkie i pokazują ryzyko wynikające nie tylko ze stężeń metali w osadach ściekowych, ale również z ich obecności w gruncie. Ponadto PERI uwzględnia stopień toksyczność metali ciężkich. Natomiast metoda ekstrakcji sekwencyjnej BCR koncentruje się na ocenie mobilności metali ciężkich. Pomimo uzyskanych różnic w wynikach, określanie omówionych wskaźników powinno być zintegrowane, aby kompleksowo dokonać oceny jakości środowiska oraz analizy ryzyka kumulacji metali ciężkich w glebach.

\section{REFERENCES}

[1] Krajowy Plan Gospodarki Odpadami 2014, Uchwała Nr 217 Rady Ministrów, z dnia 24 grudnia 2010 r., Monitor Polski, nr 101, poz. 1183.

[2] Latosińska Jolanta, Analiza mobilności metali ciężkich z osadów ściekowych z oczyszczalni ścieków w Olsztynie i Sitkówce-Nowiny, Inżynieria i Ochrona Środowiska, 2014, t. 17, nr 2, s. 243-253.

[3] Ustawa o odpadach, DzU 2013, poz. 21.

[4] Rozporządzenie Ministra Środowiska z dnia 13 lipca 2010 r. w sprawie komunalnych osadów ściekowych, DzU 2010, Nr 137, poz. 924.

[5] Rozporządzenie Ministra Gospodarki z dnia 8 stycznia 2013 r. w sprawie kryteriów oraz procedur dopuszczania odpadów do składowania na składowisku odpadów danego typu, DzU 2013, poz. 38.

[6] Rozporządzenie Ministra Rolnictwa i Rozwoju Wsi z dnia 18 czerwca 2008 roku w sprawie wykonania niektórych przepisów ustawy o nawozach i nawożeniu, DzU 2008, Nr 119, poz. 765.

[7] McGrath et al., 2000; Nilsson and Dahlström, 2005.

[8] http://www.gios.gov.pl/pl/stan-srodowiska/monitoring-jakosci-gleby-i-ziemi

[9] Gawdzik Jarosław: Mobilność wybranych metali ciężkich wosadach ściekowych. Wyd. Politechniki Świętokrzyskiej, Kielce 2013.

[10] https://www.gios.gov.pl/chemizm_gleb/index.php?mod=pomiary\&w=26

[11] Gawdzik Jarosław: Mobilność metali ciężkich w osadach ściekowych na przykładzie wybranej oczyszczalni ścieków. Inżynieria i Ochrona Środowiska 2012, t 15, nr 1, ss. 5-15.

[12] PN-EN ISO 11885:2009. Jakość wody - Oznaczanie wybranych pierwiastków metodą optycznej spektrometrii emisyjnej z plazmą wzbudzoną indukcyjnie.

[13] Żelezik Monika, Gawdzik Jarosław: The content of heavy metals species in sewage sludge from wastewater treatment plants in Mniów. Archives of Waste Water Management and Environmental Protection. 2015, nr 17, ss. 119-126.

[14] Hakanson Lars: An ecological risk index for aquatic pollutioncontrol - a sedimentological approach. Water Research 1980, 14, ss. 975-1101.

[15] Xiao Zhihua, Yuan Xing-Zhong, Leng Lijian, Jiang Longbo, Chen Xiaohong, Zhibin Wu, Xin Peng, Jiachao Zhang, Zeng Guangming: Risk assessment of heavy metals from combustion of pelletized municipal sewage sludge, Environmental Science Pollution Research, 2015.

[16] Czaplicka Anna, Ślusarczyk Zbigniew, Szarek-Gwiazda Ewa, Bazan Sonia: Rozkład przestrzenny zwiqzków żelaza i manganu w osadach dennych Jeziora Goczalkowickiego. Ochrona Środowiska 2017, vol. 39, nr 3, ss. 47-54.

[17] Zhang Jian, Tian Yu, Zhang Jun, Li Ning, Kong Lingchao, Yu Ming: Distribution and risk assessment of heavy metals in sewage sludge after ozonation. Environ. Sci. Pollut. Res. 24: 5118-5125, 2017.

[18] Singh Jiwan., Lee Byeong-Kyu: Reduction of environmental availability and ecological risk of heavy metals in automobile shredder residues. Ecol Eng 81:76-81 2015.

\section{Acknowledgments:}

The work was financed by Kielce University of Technology and Jan Kochanowski University in Kielce

\section{Podziękowania:}

Praca była finansowana przez Politechnikę Świętokrzyska, Wydziat Budownictwa i Architektury oraz Uniwersytet Jana Kochanowskiego w Kielcach 